\title{
Higher Secondary Level Students' Evaluation of Communicative Language Teaching in Bangladesh
}

\author{
Nitish Kumar Mondal ${ }^{1}$ \\ ${ }^{1}$ English Discipline, Khulna University, Khulna, Bangladesh \\ Correspondence: Nitish Kumar Mondal, English Discipline, Khulna University, Khulna-9208, Bangladesh. \\ Email: nitish.english@yahoo.com
}

Received: April 14, 2012

Accepted: June 4, $2012 \quad$ Online Published: August 21, 2012

doi:10.5539/ells.v2n3p94

URL: http://dx.doi.org/10.5539/ells.v2n3p94

\begin{abstract}
The aim of the present research was to investigate the evaluation of Communicative Language Teaching (CLT) by Higher Secondary (college) level students of Bangladesh. When EFL teachers adapt the CLT method to teach their students (especially college level education) according to their own way without perfect needs of the students, a gap has been arisen between the EFL teachers and the students for their perceptions and practice of new teaching methodology like CLT. Therefore, exploring how Higher Secondary level students' evaluation of CLT interacts with their learning process could shed more light for learners' development. This paper reports Higher Secondary level students' evaluation of CLT method by which they would be able to communicate with their teachers for learning English language very spontaneously in Bangladesh. To achieve this purpose, out of 83 participants, intermediate (Both first year and second year) language learners were selected randomly. Data were collected from semi-structured interviews and belief-inventory questionnaires in the program. It gives an interpretive account of the participant's reactions to CLT and the impact of it for learning process. This is followed by a discussion on several structured questions that students hold a favorable attitude towards CLT method which has been expressed through their positive statement that by mastering the rules of grammar, students become fully capable of communicating with a non-native speaker where CLT learners are to take responsibility for their own learning and they have to perform group work activities which are essential for communication and in promoting genuine interaction among students. Side by side they have to acquire their English knowledge for communication with others effectively when CLT method is used in their classes through text books.
\end{abstract}

Keywords: Higher Secondary, evaluation, Communicative Language Teaching, communication

\section{Introduction}

Evaluation of language teaching methods is needed for knowing the pros and cons of the methods and updating them in any language. Evaluation of language teaching method means to decide the value or quality of methods (Mondal, 2011, p.182). Kielyet al (2005) remarked about language program evaluation that "Evaluation" has been a persistent problem and it is the heart that connects and gives blood to all the other program elements and a primary focus on making judgments about language programs based on experimental designs and limited quantitative analyses (p.39). In the same way, Norris (2006) has emphasized on the evaluation program in college foreign language programs. In recent decades, teachers of English have been encouraged to implement Communicative Language Teaching (CLT) to help developing students' abilities to use English appropriately in context. CLT advocates teaching practices that develop communicative competence in authentic contexts (Larsen-Freeman, 2000). To improve students' abilities to use English in real contexts, CLT has been adopted in the settings of English as Foreign Language (EFL) colleges (Littlewood, 2007). It is clear that students' evaluations are important in their decision to learn English through CLT. The reason for the mismatch between CLT theory and practice may be teachers' attitudes (Karavas-Doukas, 1995). Since teachers' evaluation reveal teachers' thinking about teaching language, the investigation of teachers' evaluation serves as a starting point to identify the possible contradictions between teachers' beliefs and CLT principles. The idea of the communicative approach may conflict with EFL teachers' existing thoughts about teachers' roles and teaching methods. However, before 1971, the study of English was used in all level educational institutions in Bangladesh where a number of English language teaching methods are used like Translation method, Grammar-translation method, Direct method, Audio-lingual method, Humanistic Teaching Approaches, Principled Eclecticism, Task-based 
teaching and CLT (Mondal, 2012, p.168). Among the above mentioned methods, CLT method, as a teaching method, is being used both in school and college level education now, it is important to investigate Bangladeshi Higher Secondary (college) level students' evaluation of CLT.

\subsection{Background}

In the late sixties, Kelly (1969) produced an overview of language teaching history which began in the period around $500 \mathrm{BC}$ among western countries. His long historical perspective carries a message for anyone looking at the development of language teaching. But English language teaching was originated with the propagation of English nation. From the very beginning till today a number of English language teaching methods like Translation method, Grammar-translation method, Direct method, Audio-lingual method, Humanistic Teaching Approaches, Principled Eclecticism, Task-based teaching and CLT are used for learning and teaching in English language where CLT is the latest teaching method which spreads it's sweetest smells in the field of teaching and learning, especially in the modern era. Communicative Language Teaching is an approach to the teaching of second and foreign languages that emphasize communication, as both the means and the ultimate goal of learning a language (Mondal, 2012, p.317). The origins of it are to be found in the changes of the British language teaching tradition dating from the late 1960s. Wilkins' (1972) book Notional Syllabus played a significant role for the development of CLT and its greater application in the teachers and learners simultaneously. One of the most characteristic features of CLT is that it pays systematic attention to functional as well as structural aspects of language and describes spoken and written discourse. The goal of CLT is to develop communicative competence. It means what a speaker needs to know in order to be communicatively competent in a speech community which adjacent with a number of functions as: instrumental, regulatory, inter-actional, personal, and heuristic, imaginative and representational.

\subsection{Literature Review}

According to Hymes (1972), competence should be viewed as "the overall underlying knowledge and ability for language which the speaker-listener possesses" (p.13). That is, the concept of communicative competence involves knowledge of the language and the ability to use the knowledge in context. Communicative competence is a complex notion that involves linguistic as well as socio-cultural sectors. From proposed definitions, it can be concluded that communicative competence consists of knowledge of linguistic rules, appropriate language usage in different situations, connection of utterances in a discourse, and strategies to cope with for the use of language.

Burnaby and Sun (1989) reported that Chinese college students learn the knowledge of English for future jobs in China, such as reading technical articles or translation of documents.

Karava-Doukas (1996) suggests that the mismatch between the beliefs and practices may contribute to the neglect of examining teachers' attitudes before implementing any new approach. That is, only promoting the approach and trying to convince the teachers of the effectiveness of CLT does not successfully change the teachers' existing beliefs about language learning and teaching.

Widdowson (1999) says that "learners do not very readily infer knowledge of the language system from their communicative activities." "Communicative Language Teaching (CLT) values, among other things, learner-centeredness, which is, giving the learners more responsibility and involvement in the learning process. This is often achieved through discovery learning activities and through group work as opposed to the traditional teacher-fronted lesson. CLT also takes a relatively relaxed attitude towards accuracy in the belief that meaning takes precedence over form. Finally, CLT has inherited the humanist view that language is an expression of personal meaning, rather than an expression of a common culture. Such notions, it is argued, derive from very Western beliefs about education and language. Its critics argue that CLT is an inappropriate methodology in those cultural contexts where the teacher is regarded as a fount of wisdom and where accuracy is valued more highly than fluency" (Thornbury, 2003).

Chang's (2000) survey study in Taiwan investigated 110 high school English teachers' attitudes toward CLT and their practice of CLT. The results showed that Taiwanese high school English teachers hold positive attitudes toward CLT. Moreover, the teachers who hold positive attitudes toward CLT tend to use more communicative activities in their classroom practice.

Harmer (2003), according to him, the Communicative Approach has come under attack from teachers for being prejudiced in favor of native-speaker teachers by demanding a relatively uncontrolled range of language use on the part of the student, and thus expecting the teacher to be able to respond to any and every language problem which may come up. In promoting a methodology which is based around group and pair work, with teacher 
intervention kept to a minimum during, say, a role-play, the Communicative Approach may also offend against educational traditions which it aimed to supplant. The Communicative Approach has sometimes been seen as having eroded the explicit teaching of grammar with a consequent loss among students in accuracy in the pursuit of fluency.

Liao (2003) investigated high school English teachers' attitudes toward CLT in China. The first-phase survey study reported most Chinese teachers are supportive of the implementation of CLT. The findings indicated that among 302 participants, 94\% responded favorably toward CLT and were willing to practice it. In the second-phase interview study, four interviewees were selected from survey participants who displayed favorable attitudes toward CLT. The teachers expressed their agreement with CLT such as, "the teacher should take into account the students' need", and "the aim of the class is to enable students to communicate easily in real life situations" (p.125).

Karim's (2004) survey study examined university-level EFL teacher's attitudes toward CLT in Bangladesh. The findings showed that most teachers displayed positive attitudes toward the basic principles of CLT. He also interested to disclose, the teachers were aware of the features of CLT and their perceptions of CLT corresponded with their reported CLT practice.

Li's (2004) study of Chinese teachers' opinions at a tertiary level indicated that the teachers thought that learners must be given feedback when they produce L2 to modify their production. Since the students already knew how to negotiate meaning in their first language, what they needed to learn were words in order to use them in L2.

Carless's (2004) interview data study revealed that some students used the simplest linguistic forms to complete the tasks.

Hawkey (2006), in Italy, applied both survey and face-to-face interviews to investigate whether teachers agreed with the advantages of the communicative approach in language teaching. The teachers stated positive views about CLT such as "CLT improving learner motivation and interest", and "CLT improving communicative skills" (p.247). Through his research it is known that, teachers' interviews suggested that the teachers were motivated to use pair-work activities to meet the learners' communicative needs.

Razmjoo and Riazi (2006), similarly, in their study would like to depict that the teachers as a whole expressed positive attitudes toward the five principles of CLT. The teachers held strong views about CLT in the areas of grammar role and teacher role.

Hawkey (2006) reported that Italian teachers of English think some correction of grammar and lexis errors is necessary.

This view is confirmed by Tsai's (2007) study. Taiwanese teachers also thought that EFL students have no immediate need to communicate in English. On the other hand, they need grammar and reading skills in order to learn content knowledge.

\subsection{Statement of the Problem}

The present research was designed to investigate the higher secondary level students' evaluation of the CLT (Which is specially used at higher secondary/college level education) in Bangladesh.

\subsection{Objectives}

The objectives of the study were implemented through following specific questions:

1) How the CLT method is evaluated by the higher secondary level students in English language teaching in Bangladesh?

2) What are the characteristics of the CLT method?

3) How the CLT method can be used meaningfully?

\subsection{Significance of the Study}

This study has great importance for both the students and teachers alike. Especially the students of the schools, colleges and even in advance level (University) education would be able to know the perfect idea about CLT which play a vital role in the field of learning and teaching practices equally. As this study has collected a lot of information about the method, the effectiveness and appropriateness of the method will be made meaningful. Furthermore, the study will guide the English teachers in exploring proper methodologies for teaching through CLT. The significance of the study will also be for the planners and education managers in policy formulation or revision of teacher education programs at secondary, higher secondary and even in advance level education in the country. It will also help in-service teacher education institution to award or offer relevant in service i.e. 
training programs. In addition, the students, teachers and general people of the country will be able to use this method in the classroom and out of the classroom frequently. It will also help the people (who are not actually the students) who are interested in CLT for communicating with the foreigners. Moreover, the students (especially both secondary and higher secondary level) will have four skills of language by which they will be able to learn language very smoothly and apply it with others without any hesitation.

\section{CLT in Bangladesh and Characteristics of CLT}

Though this method was started in England in the early 19th century but it was introduced for teaching English at secondary education in Bangladesh in 2001 and similarly introduced in the higher secondary courses and is being continued till today. In Bangladesh, a number of methods were initiated at the colonial period (Atthat time Grammar-Translation method was the most popular one). As English enjoyed very prestigious position during colonial period, due attention was given in teaching this language in undivided India. It continued as a colonial leftover after 1947 till 1971. With the independence of Bangladesh in 1971, the policy makers of this country diminished the importance of English and they changed this English Language Teaching Method (ELTM) correlation with their various domains of using both quantitative and qualitative measures, parametric and non-parametric measures of ELTM which were used to test hypothesis without knowing the authentic and fundamental needs of the students and the proficiency of the teachers. As a result, teaching of English in Bangladesh experienced different dimension regarding its curriculum, syllabus, materials, methodology, testing and evaluation. It also experienced a mismatch between different components of the program. Different methods have been found to be used where CLT is the latest method of teaching language. This method is developed by the English Language Teaching Improvement Project (ELTIP). The purpose of using this method in Bangladesh was to update the English language teaching at the Secondary education in Bangladesh meaningfully. ELTIP started working since July 1997 . The project is sponsored by the ministry of education. This project has been working to promote teaching learning of English in the Secondary level education in Bangladesh and introduced the communicative language teaching approach in the English curriculum of the country for the first time. Afterwards this method is used in higher secondary (college) level education in Bangladesh and changed a little with the passage of time without knowing the perfect demands and evaluation of the students. Therefore, it becomes necessary to examine the higher secondary level students' evaluation of CLT in Bangladesh.

According to Rodgers (2001), there are four characteristics of the communicative view of language:

1) Language is a system for the expression of meaning.

2) The primary function of language is to allow interaction and communication.

3) The structure of language reflects its functional and communicative uses.

4) The primary units of language are not merely its grammatical and structural features, but categories of function and communicative meaning as exemplified in discourse.

\section{Methodology}

The methodology of this research describes the location of the study followed by sampling procedures employed in the study, a profile of the informants, and method of data collection, instrumentation, data collection procedures and data analysis procedures.

\subsection{Location and Informants of the Study}

This research examined the evaluation of English language teaching method like CLT by the Higher Secondary level students in Bangladesh through a number of colleges of south-western part of the country where Khulna, Satkhira, Bagerhat and Jessore districts were included. The informants were first year and second year students of the different colleges. The research had both male and female informants.

\subsection{Sampling and Instrumentation Procedures}

The population of this research was Higher Secondary level (college) students. A total of 83 students were selected as the sample for this research. The respondents were from the different colleges in four districts. The sample was selected through a random sampling method. A total of 83 Higher Secondary level students were selected as respondents to whom the questionnaire was administered to collected data for this research. The questionnaire was prepared through English language. This research is descriptive and non-experimental. The research was based on primary data. The data were collected via the survey approach through a self-administrated questionnaire. The questionnaire survey method was preferred because the researcher investigated informant's evaluation of English language teaching Method like CLT used at Secondary and Higher Secondary education in Bangladesh. This method was chosen because of the following reasons: (I) this 
method is suitable for empirical research; (II) the data collected through this method is easily quantifiable; (III) this method gives informants enough time to provide well thought out answers; (IV) this offers grater anonymity to the informants; and (V) this requires low cost and saves time. The questionnaire was prepared by researcher in connection the research demands. In preparing the questionnaire, caution was exercised to ensure the standard and quality of the questions. The researcher was concerned about the validity, reliability, clarity, practicality, administer ability of the instruments. A pilot survey was conducted to study the feasibility of the instruments. The feedback from this pilot survey on the appropriateness of the questionnaire was then incorporated into the questionnaire and approved of administration.

\subsection{Data Collection and Analysis Procedures}

Quantitative method was used to collect the data. The data was collected through a survey in the form of a questionnaire. The questionnaires were administrated by the researcher himself. The questionnaires were distributed to the students of the colleges and requested them to return the completed questionnaires after answering. Upon completion of the correction of data, the data was edited, coded classified and tabulated for computation and analysis. The analysis was done using SPSS (statistical package for social sciences) software. This software was used to examine and investigate about students' choice of answer through which the percentage values were obtained.

Data collected were tabulated, analyzed, interpreted and presented in Table 1 below. Percentage was calculated by using statistical technique for evaluation. The short terms which are used in the chart are described below:

$$
\begin{aligned}
& \mathrm{SA}=\text { Strongly Agreed } \\
& \mathrm{A}=\text { Agreed } \\
& \mathrm{UNC}=\text { Uncertain } \\
& \mathrm{DA}=\text { Disagreed } \\
& \mathrm{SDA}=\text { Strongly Disagreed }
\end{aligned}
$$

\section{Findings and Discussions}

The following findings were drawn on the basis of question analysis of the questionnaire:

1. In answering the structured question "Do you think that the learners with little or no knowledge of the language cannot communicate with others effectively?" about $38.55 \%$ respondents strongly agreed with the statement that the learners with little or no knowledge of the language cannot communicate with others effectively.

2. In answering the structured question "Are you agree that CLT learners are to take responsibility for their own learning without the help of others?" $34.94 \%$ respondents strongly disagreed with the statement that CLT learners are to take responsibility for their own learning without the help of others.

3. In answering the structured question "Do you think that the students should become effective communicators in the foreign language only for communication?" $32.53 \%$ respondents strongly agreed with the statement that the students should become effective communicators in the foreign language only for communication.

4. In answering the structured question "Is CLT the most important factor by which language Performance should be judged?" $39.76 \%$ respondents strongly agreed with the statement and they think CLT is the most important factor by which language Performance should be judged.

5. In answering of the structured question "Do you think group work activities are essential for communication and in promoting genuine interaction among students?" $33.73 \%$ respondents strongly agreed with the statement that group work activities are essential for communication and in promoting genuine interaction among students.

6. In answering the structured question "Do you think that a textbook alone is not able to cater to all the needs and interests of the students?" $31.33 \%$ respondents strongly agreed with the statement that a textbook alone is not able to cater to all the needs and interests of the students.

7. In answering the structured question "Do you think that the students do their best when CLT is taught in their class by the teacher?" $34.94 \%$ respondents strongly agreed with the statement and think that the students do their best when CLT is taught in their class by the teacher.

8. In answering the structured question "Do you think that it is very difficult for the teachers to monitor the students' performance and prevent them from using their mother tongue?" $28.92 \%$ respondents disagreed with 
the statement and think that it is very difficult for the teachers to monitor the students' performance and prevent them from using their mother tongue.

9. In answering the structured question "Do you think that teachers are the authentic factor for performing CLT in the course of a lesson?" $27.72 \%$ respondents strongly agreed with the statement that teachers are the authentic factor for performing CLT in the course of a lesson.

10. In answering the structured question "Do you think that by mastering the rules of grammar, students become fully capable of communicating with a non-native speaker?" $32.53 \%$ respondents disagreed with the statement and think that by mastering the rules of grammar; students become fully capable of communicating with a non-native speaker.

11. In answering the structured question "Do you think that most of the students acquire their English knowledge for communication with others effectively when CLT is used in their classes through text book?" $37.35 \%$ respondents strongly agreed with the statement and think that most of the students acquire their English knowledge for communication with others effectively when CLT is used in their classes through text book.

12. In answering the structured question "Do you think that the role of the teacher in the language classroom is to impart knowledge through activities such as explanation, writing, and example?" $32.53 \%$ respondents strongly agreed with the statement and think that the role of the teacher in the language classroom is to impart knowledge through activities such as explanation, writing, and example.

The result is drawn up through data analysis and findings of the research. When designing the evaluation of the Higher Secondary level students towards CLT method used in English language teaching, the present research could address the focal evaluation questions, so it designed corresponding questions to obtain information about that theme desired. The questions the study implemented were highly structured and the students' answers and responses to the questions helped to continue the research effectively. When analyzing the data, it also obtained a clearer picture of the implementation status of the current research.

\section{Conclusion}

CLT represents the current trend of college level English language education that aims to develop learners' communicative competence. Although teachers play a crucial role in preparing students to communicate effectively in various situations, students are the authentic factor for this issue. This study was motivated to investigate Bangladeshi Higher Secondary level students' evaluation of CLT method and their thinking about CLT in practice. The findings reveal that students hold a favorable attitude towards CLT method and display characteristics of CLT in their beliefs. On the basis of six star marked questions, it can be expressed that 32 respondents strongly agreed with the statement that the learners with little or no knowledge of the language cannot communicate with others effectively and 29 strongly disagreed with the statement that CLT learners are to take responsibility for their own learning without the help of others where 33 respondents strongly agreed and(28 respondents strongly agreed with the statement) think that group work activities are essential for communication and in promoting genuine interaction among students. Moreover, 27 respondents were disagreed and interested proclaiming that without mastering the rules of grammar, students don't become fully capable of communicating with a non-native speaker where respondents strongly agreed with the statement and think that most of the students acquire their English knowledge for communication with others effectively when CLT is used in their classes through text book.

\section{References}

Burnaby, B., \& Sun, Y. (1989). Chinese Teachers' Views of Western Language Teaching: Context Informs Paradigms. TESOL Quarterly, 23(2), 219-237. http://dx.doi.org/10.2307/3587334

Carless, D. (2004). Issues in Teachers' Reinterpretation of a Task-Based Innovation in Primary Schools. TESOL Quarterly, 38(4), 639-662. http://dx.doi.org/10.2307/3588283

Chang, L. U. (2000). Communicative Language Teaching: Senior High School English Teachers' Belief and Practice, (Unpublished Master Thesis). Tamkang University.

Hawkey, R. (2006). Teacher and Learner Perception of Language Learning Activity. ELT Journal, 60(3), 242-252. http://dx.doi.org/10.1093/elt/ccl004

Hymes, D. H. (1972). On Communicative Competence. In C. J. Brumfit \& K. Johnson (Eds.), The Communicative Approach To Language Teaching (2nd ed., pp. 5-27). Oxford: Oxford University Press.

Jeremy, H. (2003). How to Teach English. Beijing: Foreign Language Teaching and Research Press. 
Karavas-Doukas, E. (1995). Teacher Identified Factors Affecting the Implementation of an EFL Innovation. In Greek Public Secondary Schools, Language, Culture and Curriculum, 8(1), 53-68. http://dx.doi.org/10.1080/07908319509525188

Karavas-Doukas, E. (1996). Using Attitude Scales to Investigate Teachers' Attitude to the Communicative Approach, ELT Journal, 50(3), 187-198. http://dx.doi.org/10.1093/elt/50.3.187

Karim, K. M. R. (2004). Teachers' Perceptions, Attitudes, and Expectations about Communicative Language Teaching (CLT) in Post-Secondary Education in Bangladesh, (Unpublished Master Thesis). University of Victoria.

Kelly, L. G. (1969). 25 Centuries of Language Teaching Rowley. Mass: Newbury House.

Kiely, R., \& Rea-Dickins, P. (2005). Program Evaluation in Language Education. Hampshire and New York: Palgrave Macmillan. http://dx.doi.org/10.1057/9780230511224

Larsen-Freeman, D. (2000). Techniques and Principles in Language Teaching. Oxford: Oxford University Press.

Li, P. (2004). Chinese EFL Teachers Perceptions of Implementation of Communicative Language Teaching at Tertiary Level, (Unpublished Doctoral Dissertation). McGill University.

Liao, X. (2003). Chinese Secondary School Teacher's Attitude toward Communicative Language Teaching and Their Classroom Practice, (Unpublished Doctoral Dissertation).The University of Auckland.

Littlewood, W. (2007).Communicative and Task-based Language Teaching in East Asian Classrooms. Language Teaching, 40, 243-249. http://dx.doi.org/10.1017/S0261444807004363

Mondal, N. K. (2011). Evaluation of English Language Teaching Methods Used in Higher Secondary Education in Bangladesh. Language in India (Vol. 11, No. 12, pp. 181-197). Retrieved February 05, 2012, from http://www.languageinindia.com

Mondal, N. K. (2012a). Assessment of English Teaching Methodologies at Secondary Level in Bangladesh. Language in India (Vol.12, No.1, pp. 310-327). Retrieved February 5, 2012, from http://www.languageinindia.com

Mondal, N. K. (2012b). English Language Teaching through the Translation Method at Secondary Level Education in Bangladesh. Journal of American Science, 8(1), 168-173. Retrieved February 5, 2012, from http://www.americanscience.org

Norris, J. M. (2006). The Why (and How) of Student Learning Outcomes Assessment in College FL Education. Modern Language Journal, 90(4), 590-597. http://dx.doi.org/10.1111/j.1540-4781.2006.00466_2.x

Razmjoo, S. A., \& Riazi, A. (2006). Do High Schools Or Private Institutes Practice Communicative Language Teaching? A Case Study of Shiraz Teachers' in High Schools and Institutes. The Reading Matrix, 6(3), 363.

Rodgers, T. (2001). Cooperative Language Learning: What's new? PASAA: A Journal of Language Teaching And Learning.

Thornbury, S. (2003). How to Teach Grammar. Beijing: World Affairs Press.

Tsai, T. H. (2007). Taiwanese Educators' Perspective on the Implementation of the New English Education Policy, (Unpublished Doctoral Dissertation). Alliant International University.

Widdowson, H. (1999). Aspects of Language Teaching. Shanghai: Shanghai Foreign Language Education Press. Wilkins, D. A. (1972). A Linguistics in Language Teaching. London: Arnold. 


\section{Appendix}

Table 1. Frequency and Percentage of Participants' Opinions toward the English $(\mathrm{N}=83)$

\begin{tabular}{|c|c|c|c|c|c|}
\hline Questions & SA & A & $\mathrm{U}$ & $\mathrm{D}$ & SD \\
\hline 1.Do you think that the learners with little or no & 32 & 19 & 8 & 11 & 13 \\
\hline $\begin{array}{l}\text { knowledge of the language, cannot communicate with } \\
\text { others effectively?* }\end{array}$ & $38.55 \%$ & $22.89 \%$ & $9.64 \%$ & $13.25 \%$ & $15.66 \%$ \\
\hline 2.Are you agree that CLT learners are to take & 15 & 12 & 9 & 18 & 29 \\
\hline $\begin{array}{l}\text { responsibility for their own learning without the help of } \\
\text { others?* }\end{array}$ & $18.07 \%$ & $14.46 \%$ & $10.84 \%$ & $21.69 \%$ & $34.94 \%$ \\
\hline 3.Do you think that the students should become effective & 27 & 21 & 12 & 14 & 9 \\
\hline $\begin{array}{l}\text { communicators in the foreign language only for } \\
\text { communication? }\end{array}$ & $32.53 \%$ & $25.30 \%$ & $14.46 \%$ & $16.87 \%$ & $10.84 \%$ \\
\hline 4.Is CLT the most important factor by which & 33 & 22 & 3 & 13 & 12 \\
\hline languagePerformance should be judged?* & $39.76 \%$ & $26.51 \%$ & $3.61 \%$ & $15.66 \%$ & $14.46 \%$ \\
\hline 5.Do you think group work activities are essential for & 28 & 23 & 2 & 17 & 13 \\
\hline $\begin{array}{l}\text { communication and in promoting genuine interaction } \\
\text { among students?* }\end{array}$ & $33.73 \%$ & $27.72 \%$ & $2.41 \%$ & $20.48 \%$ & $15.66 \%$ \\
\hline 6.Do you think that a textbook alone is not able to cater & 26 & 24 & 1 & 21 & 11 \\
\hline toall the needs and interests of the students? & $31.33 \%$ & $28.92 \%$ & $1.20 \%$ & $25.30 \%$ & $13.25 \%$ \\
\hline 7. Do you think that the students do their best when CLT is & 29 & 23 & 6 & 15 & 10 \\
\hline taught in their class by the teacher? & $34.94 \%$ & $27.72 \%$ & $7.23 \%$ & $18.07 \%$ & $12.05 \%$ \\
\hline $\begin{array}{l}\text { 8. Do you think that it is very difficult for the teachers } \\
\text { tomonitor the students' performance andprevent them } \\
\text { from using their mothertongue? }\end{array}$ & $\begin{array}{c}18 \\
21.69 \%\end{array}$ & $\begin{array}{c}21 \\
25.30 \%\end{array}$ & $\begin{array}{c}5 \\
6.02 \%\end{array}$ & $\begin{array}{c}24 \\
28.92 \%\end{array}$ & $\begin{array}{c}15 \\
18.07 \%\end{array}$ \\
\hline $\begin{array}{l}\text { 9.Do you think thatteachers are the authentic factor for } \\
\text { performingCLT in the course of a lesson? }\end{array}$ & $\begin{array}{c}23 \\
27.72 \%\end{array}$ & $\begin{array}{c}19 \\
22.89 \%\end{array}$ & $\begin{array}{c}4 \\
4.82 \%\end{array}$ & $\begin{array}{c}18 \\
21.87 \%\end{array}$ & $\begin{array}{c}19 \\
22.89 \%\end{array}$ \\
\hline 10.Do you think thatby mastering the rules of & 17 & 22 & 5 & 27 & 12 \\
\hline $\begin{array}{l}\text { grammar,students become fully capable ofcommunicating } \\
\text { with a non-native speaker?* }\end{array}$ & $20.48 \%$ & $26.51 \%$ & $6.02 \%$ & $32.53 \%$ & $14.46 \%$ \\
\hline 11.Do you think that most of the students acquire their & 31 & 29 & 2 & 11 & 10 \\
\hline $\begin{array}{l}\text { English knowledge for communication with others } \\
\text { effectively when CLT is used in their classes through text } \\
\text { book?* }\end{array}$ & $37.35 \%$ & $34.94 \%$ & $2.41 \%$ & $13.25 \%$ & $12.05 \%$ \\
\hline 12.Do you think thatthe role of the teacher in the & 27 & 19 & 8 & 18 & 11 \\
\hline $\begin{array}{l}\text { languageclassroom is to impart knowledge } \\
\text { throughactivities such as explanation, writing, and } \\
\text { example? }\end{array}$ & $32.53 \%$ & $22.89 \%$ & $9.64 \%$ & $21.87 \%$ & $13.25 \%$ \\
\hline
\end{tabular}

On the basis of the results and discussions (where twelve questions are structured) a pie chart can be drawn in the following way through taking the highest percentages of star $(*)$ marked six questions.
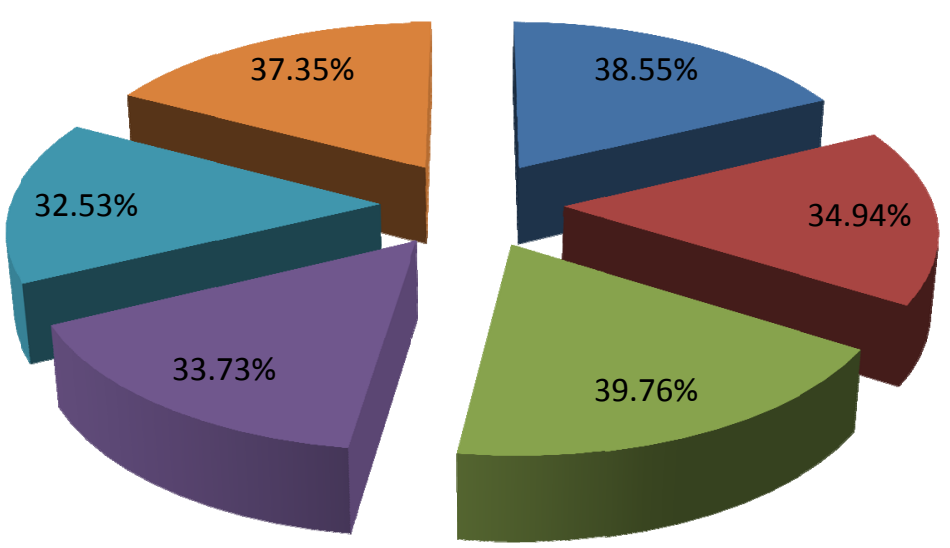